\title{
Wpływ przezczaszkowej stymulacii prądem stałym na funkcjonowanie poznawcze chorych po uszkodzeniu mózgu
}

\author{
Influence of transcranial direct current stimulation on cognitive functioning of patients \\ with brain injury
}

Katarzyna Polanowska, Joanna Seniów

II Klinika Neurologiczna, Instyłut Psychiatrii i Neurologii w Warszawie

Neurologia i Neurochirurgia Polska 2010; 44, 6: 580-590

\section{Streszczenie}

Następstwa kliniczne uszkodzeń mózgu nie są jedynie wynikiem samego uszkodzenia, ale też efektem dynamicznych zmian aktywacyjnych zachodzących w naruszonych sieciach neuronalnych, które to zmiany mogą być mało adaptacyjne. Przezczaszkowa stymulacja prądem stałym (transcranial direct current stimulation - tDCS), dostarczając do kory mózgowej słaby polaryzujący prąd stały, służy modulowaniu wzbudzenia korowego. Charakter zmiany korowej zależy od biegunowości elektrod: stymulacja anodowa zwiększa wzbudzenie i spontaniczną aktywność korową, a stymulacja katodowa redukuje je. Udowodniono, że modulacji korowej powodowanej tDCS towarzyszą zmiany wskaźników poznawczych. W większości analizowanych dotąd schematów badawczych, wzrost wzbudzenia wywołany stymulacją anodową korzystnie wpływał na procesy uczenia się i zapamiętywania, uwagę i zdolności językowe. W tym kontekście tDCS jawi się jako obiecująca metoda usprawniania poznawczego pacjentów z różnymi chorobami neurologicznymi, m.in. z udarem mózgu i schorzeniami neurodegeneracyjnymi. Wystawienie mózgu na działanie prądu stałego może pomóc w swoistym i wybiórczym wzmacnianiu adaptacyjnych wzorców aktywacji, tłumieniu wzorców nieadaptacyjnych i równoważeniu międzypółkulowych interakcji aktywacyjnych.

Słowa kluczowe: przezczaszkowa stymulacja prądem stałym, polaryzacja mózgu, funkcje poznawcze.

\begin{abstract}
Clinical consequences of brain injuries are not simply the result of the initial insult, but also reflect dynamic changes of activity in disrupted neural networks, some of which might be maladaptive. Transcranial direct current stimulation (tDCS), which delivers weak polarizing direct currents to the cortex, is used to modulate cortical excitability. The nature of neuromodulation depends on the stimulation polarity: anodal stimulation increases cortical excitability while cathodal stimulation reduces it. It has been demonstrated that tDCSinduced brain modulations are associated with cognitive changes. In most paradigms tested, excitability-enhancing anodal tDCS proved beneficial to learning and memory processes, attention, and linguistic skills. In this context, tDCS appears to be a promising method to improve cognitive functions in patients with various neurological disorders, including stroke and neurodegenerative diseases. Exposure to brain polarization may help in specific and selective enhancement of adaptive patterns of activity, suppression of non-adaptive activation patterns, and balancing interhemispheric interactions.
\end{abstract}

Key words: transcranial direct current stimulation, brain polarisation, cognitive functions.

Adres do korespondencji: dr Katarzyna Polanowska, II Klinika Neurologiczna, Instytut Psychiatrii i Neurologii, ul. Sobieskiego 9,

02-957 Warszawa, e-mail: kpolanow@ipin.edu.pl

Prace otrzymano: 16.05.2010; przyięto do druku: 31.08.2010 


\section{Wprowadzenie}

Niedługo po tym, jak na przełomie XVIII i XIX w. włoscy uczeni Luigi Galvani i Alessandro Volta odkryli fizjologiczne skutki działania bodźców elektrycznych, prąd stały, zwany galwanicznym, zaczęto wykorzystywać w leczeniu chorych z zaburzeniami psychicznymi. Pierwsze obserwacje efektów przepuszczania przez ludzką czaszkę prądu stałego były zróżnicowane, m.in. z powodu stosowania odmiennych i niejasno opisanych procedur elektrostymulacji $[1,2]$. Dużym postępem w elektrolecznictwie okazało się wprowadzenie w 1938 r. przez Ugo Cerlettiego i Lucio Biniego zabiegów elektrowstrząsowych u chorych na depresję [3]; bezpieczeństwo tych zabiegów zwiększało się wraz z rozwojem stosowania prądów zmiennych [4]. Do badań nad leczniczym działaniem prądu stałego powrócono dopiero w latach $60 . \mathrm{XX}$ w. W przeprowadzonych wówczas eksperymentach na zwierzętach wykazano, że przepuszczanie przez korę mózgu słabego, jedynie polaryzującego tkanki, prądu stałego (1 lub $2 \mathrm{~mA}$ ) powoduje umiarkowaną (ok. 40-procentową) zmianę stopnia wzbudzenia kory [5]. Charakter indukowanej zmiany korowej zależy od biegunowości elektrod, gdyż dodatnia elektrostymulacja anodowa (działanie anody na znajdujące się pod nią tkanki) zwiększa poziom wzbudzenia, a stymulacja katodowa (dotyczy tkanek pod katodą) powoduje depresję aktywacyjną. Oczywiście w obwodach prądu stałego przepływ ładunku elektrycznego zachodzi pomiędzy dwiema odmiennie spolaryzowanymi elektrodami, dlatego oprócz wyróżnionej elektrody, zwanej aktywną (stąd pojęcie elektrostymulacji aktywnej), jest też elektroda odniesienia: anoda dla katody, a katoda dla anody. W zabiegach przezczaszkowych umieszczenie nad jedną półkulą mózgu elektrody aktywnej, a nad drugą elektrody odniesienia powoduje, że stymulowane są jednocześnie obie półkule, ale zamocowanie elektrody odniesienia poza obrębem głowy (np. na przedramieniu) ogranicza stymulację praktycznie do jednej półkuli, gdyż prąd najsilniej działa pod elektrodami i w tym rejonie dociera do mózgu [6].

Dalsze badania na zwierzętach oraz zainspirowane w 1998 r. przez Prioriego [7] badania zdrowych ochotników potwierdziły wczesne obserwacje co do wpływu prądu stałego na mózg $[8,9]$ oraz pokazały, że neuromodulacji towarzyszą zmiany parametrów funkcji ruchowych, percepcyjnych i poznawczych. Co ciekawe, zmiany wzbudzeniowe $\mathrm{i}$ ich następstwa funkcjonalne ujawniają się nie tylko podczas trwania zabiegu (efekt śródstymulacyjny), lecz także po jego zakończeniu (postymulacyjny efekt następczy), jeśli stymulacja trwa co najmniej 3 min $[1,8]$. Zwiększenie natężenia i czasu podawania prądu przedłuża następczą neuromodulację do ponad godziny [10]. Odkrycie to spowodowało, że metoda przezczaszkowej stymulacji prądem stałym (transcranial direct current stimulation - tDCS) okazała się nie tylko użyteczna w badaniu procesów mózgowych warunkujących ekspresję różnych funkcji, ale także uznano ją za potencjalne narzędzie do terapii chorych z zaburzeniami czynności ośrodkowego układu nerwowego (OUN) [11].

\section{Dlaczego łagodna polaryzacja mózgu prąem stałym przynosi efekty behawioralne?}

Czynnościowe badania obrazowe układu nerwowego potwierdzają, że kliniczne następstwa uszkodzenia mózgu nie są jedynie wynikiem zmian strukturalnych, ale też współistniejących zaburzeń aktywacyjnych, które ujawniają się w obrębie naruszonych obwodów neuronalnych [12]. Obraz odpowiedzi aktywacyjnej OUN na uszkodzenie zmienia się dynamicznie wraz z przebiegiem choroby neurologicznej - zdrowieniem bądź jej postępowaniem. Zmiany te, opisywane w kategoriach neuroplastyczności kompensacyjnej, są przejawem dążenia systemów mózgowych do utworzenia nowych zależności wzbudzeniowych pomiędzy przetrwałymi częściami sieci [13]. Złożona kompensacja aktywacyjna obejmuje zarówno procesy o korzystnym znaczeniu dla zachowania i aktywności poznawczej chorego, jak i zjawiska, które nie prowadzą do widocznych korzyści klinicznych, a nawet nasilają deficyt i pogarszają wynik terapii - tzw. fałszywe kompensacje. Zgodnie z założeniami teoretycznymi i wynikami dotychczasowych badań, poddanie mózgu działaniu prądu stałego może pomóc w swoistym i wybiórczym wzmacnianiu adaptacyjnych wzorców aktywacyjnych, tłumieniu wzorców niekorzystnych i odbudowie równowagi aktywacyjnej półkul [12].

Badania nad efektywnością tDCS w neurorehabilitacji są dopiero w początkowej fazie. Niniejsza praca zawiera ich przegląd w odniesieniu do pacjentów po udarze mózgu i osób z chorobami neurodegeneracyjnymi. W większości zostały one przeprowadzone z zastosowaniem tzw. ślepych prób (uniemożliwienie uczestnikom i obserwatorom badania odkrycia typu stymulacji), z wykorzystaniem placebo, rozumianego jako pozorowanie efektywnej stymulacji albo oddziaływanie 
na części kory niezaangażowanej w regulację analizowanych funkcji. Zorientowanie się w typie stymulacji utrudniał fakt, że nawet krótkotrwały przepływ prądu powoduje podrażnienie receptorów skórnych i przemijające uczucie mrowienia. Na tej podstawie zarówno badani z grupy stymulowanej, jak i z grupy placebo mogli uznać zabieg za terapeutyczny i powiadomić o tym obserwatora. Tymczasem dopiero tDCS trwająca powyżej kilku minut prowadzi do skutecznej neuromodulacji, stosowanej tylko w grupie aktywnie stymulowanej [14].

\section{Stosowanie przezczaszkowei stymulacji prq̨dem stałym u chorych po udarze mózgu}

Duże nadzieje wiąże się ze wspieraniem metodą tDCS specyficznego treningu poznawczego u chorych po udarze mózgu [15-17], u których obserwuje się zróżnicowane zaburzenia aktywacyjne [12]. Modele zdrowienia w przypadku udaru niedokrwiennego opracowane na przykładzie chorych $\mathrm{z}$ afazją, ale mające zastosowanie również w innych zaburzeniach - wskazują, że po wczesnej fazie rozległej depresji aktywacyjnej (odpowiadającej zjawisku diaschizy) dochodzi do stopniowych zmian aktywacyjnych w systemach neuronalnych. Podczas nich ustalają się nowe relacje aktywacyjne pomiędzy przetrwałymi częściami sieci neuronalnych [13], oparte na interakcjach typu wzbudzanie-hamowanie [18]. Najwięcej korzystnych zmian rozpoczyna się w podostrej fazie udaru, ok. drugiego tygodnia od zachorowania. W tym czasie rejestruje się często względną nadmierną aktywację półkuli nieuszkodzonej strukturalnie, powodowaną brakiem hamujących projekcji z półkuli uszkodzonej, tj. hipoaktywnej. Spontanicznie uruchomione procesy samonaprawcze mogą doprowadzić do znacznej korekty nieprawidłowości aktywacyjnych. W przypadku niewielkich ognisk udarowych może dojść do samoistnego znormalizowania poziomów aktywacji mózgowej, co sprzyja poprawie funkcjonalnej. Przy dużych uszkodzeniach stronnych mózgu bywa, że zakłócenia aktywacyjne utrwalają się we wzorcu hiperaktywacji półkuli zdrowej i hipoaktywacji półkuli uszkodzonej. Zdaniem niektórych badaczy, np. Perani i wsp. [19], podwyższona aktywność półkuli nieuszkodzonej w rejonach homologicznych do ogniska dowodzi przynajmniej częściowego przejmowania przez te okolice mózgu funkcji struktur zniszczonych i w tym sensie sprzyja zdrowieniu. Taka aktywność mózgowa zwykle nie wystarcza jednak do skompensowania wyraźnego ubytku funkcjonalnego, a nowa strategia regulacji funkcji może być mało adaptacyjna [17], dlatego inni autorzy uważają to zjawisko za negatywne. Według nich, znaczna dysproporcja względnych poziomów aktywacji półkul dodatkowo rozregulowuje czynność uszkodzonych obwodów neuronalnych i nasila dysfunkcję. Co gorsza, przedłużające się nadmierne przezspoidłowe hamowanie półkuli hipoaktywnej przez półkulę nadmiernie aktywną stabilizuje tę pierwszą we wzorcu niedostatecznego wzbudzenia, osłabiając procesy samonaprawcze w jej obszarze [20].

W celu zmniejszenia tonicznych różnic aktywacyjnych między półkulami mózgu można wykorzystać stymulację zwiększająca poziom wzbudzenia półkuli uszkodzonej, przykładając ponad nią anodę (stymulacja anodowa, a-tDCS), i/lub stymulację obniżającą pobudliwość półkuli zdrowej poprzez przyłożenie katody (stymulacja katodowa, k-tDCS) $[1,12,16,17]$. W opublikowanych dotąd kilku pilotażowych badaniach z udziałem chorych po udarze mózgu, podostra faza udaru była najwcześniejszym okresem wprowadzenia tego typu technik [12]. Dostarczyły one wstępnych danych o związku polaryzacji mózgu z poprawą funkcji mowy i języka, pamięci i uwagi.

Hesse $\mathrm{i}$ wsp. [21] pierwsi zwrócili uwagę na zmiany sprawności poznawczych towarzyszące użyciu tDCS u chorych po udarze mózgu. Badacze chcieli sprawdzić na przykładzie 10 chorych z niedowładem połowiczym, jaka jest tolerancja zabiegu przezczaszkowej elektrostymulacji. Do 30 sesji treningu ruchowego dołączyli 7-minutową a-tDCS o sile $1,5 \mathrm{~mA}$, nacelowaną na korę ruchową półkuli uszkodzonej (anoda ponad C3/C4 wg systemu elektroencefalograficznego 10/20). Analiza wyników pokazała, iż u 4 z 5 pacjentów, u których niedowładowi prawostronnemu towarzyszyła afazja, nieoczekiwanie zmniejszyły się zaburzenia językowe, oceniane za pomoca testu afazji (Aachener Aphasie Test). Zmniejszenie zaburzeń językowych polegało na zamianie afazji całkowitej w czuciową, a czuciowej w anomiczną i ogólnym złagodzeniu objawów zespołu. Należy przy tym dodać, że korzystne zmiany dotyczyły chorych będących we względnie wczesnym okresie zachorowania (między 4. a 8. tygodniem od udaru), kiedy odnotowuje się największy wskaźnik poprawy związany ze spontanicznym zdrowieniem [22]. Działania terapeutyczne podjęte w tym czasie służą przede wszystkim wspomaganiu naturalnych procesów normalizacji aktywacyjnej i reorganizacji funkcjonalnej mózgu. Nie można zatem wykluczyć, że odnotowana poprawa językowa była 
w dużym stopniu wynikiem samoistnego powrotu funkcji, tym bardziej że pomiary testowe wykonano po ponadsześciotygodniowym okresie zdrowienia. Chorzy z afazją zostali też poddani treningowi językowemu, którego wpływu również nie rozważono.

Inny charakter miało badanie przeprowadzone przez Monti i wsp. [23] w grupie 8 chorych z wieloletnią (2-8 lat po udarze) afazją ,niepłynną” (afazja ruchowa i całkowita). W ocenie funkcji językowych wykorzystano skróconą wersję Testu Żetonów (Token Test), mierzącego rozumienie, oraz zestaw zadań do oceny zdolności ekspresji językowej, rozumienia, pisania i czytania. Badanie skutków polaryzacji lewej okolicy czołowo-skroniowej zaprojektowano tak, że 6 pacjentów poddano w losowej kolejności pojedynczym zabiegom a-tDCS i pozorowanej tDCS, a 6 innych - k-tDCS i stymulacji pozorowanej. Faktyczna stymulacja o intensywności $2 \mathrm{~mA}$ trwała $10 \mathrm{~min}$. W jej trakcie elektroda aktywna (anoda lub katoda zależnie od podgrupy) znajdowała się nad okolicą Broki (miejsce przecięcia linii wyprowadzonych z punktów T3-Fz i F7-Cz zgodnie z systemem EEG 10/20), a elektroda odniesienia - na prawym ramieniu. Jako placebo wykorzystano nieefektywną, tj. zbyt krótką (10 s), elektrostymulację oraz stymulację katodową kory potylicznej, nienależącej do neuronalnego systemu językowego. Stwierdzono, że zarówno stymulacja pozorowana, jak i wariant polaryzacji anodowej pola Broki i k-tDCS kory potylicznej nie spowodowały poprawy aktualizacji nazw, natomiast stymulacja katodowa okolicy Broki doprowadziła do wzrostu poprawności nazywania o $34 \%$. W przeciwieństwie do poprzedniego badania, w tym przypadku trudno poprawę językową wiązać z samoistnym zdrowieniem, jako że u badanych uszkodzenie mózgu nastąpiło dawno, a w fazie chronicznej biologiczne procesy samonaprawcze są zminimalizowane.

Poza afazją poudarową, która nierzadko jest przedmiotem badań z powodu częstego występowania i dramatycznych konsekwencji funkcjonalnych, uwaga badaczy skupiła się także na wspomaganiu za pomocą tDCS procesów pamięciowych. Procesy te leżą u podstaw uczenia się oraz nabywania nowych umiejętności i mają zasadnicze znaczenie dla odbudowy zróżnicowanych sprawności oraz adaptacji do życia z nabytym deficytem. Funkcje pamięciowe regulowane są przez szereg systemów mózgowych, spośród których kluczowe struktury limbiczne (m.in. hipokamp, ciała suteczkowate, ciało migdałowate) są na tyle głęboko zlokalizowane, że łagodne formy stymulacji powierzchniowych warstw kory mają dla nich małe znaczenie aktywacyjne. Dlatego też poszukuje się zależności między stymulacją prądem stałym a czynnościami mnestycznymi regulowanymi w dominujący sposób przez korowe sieci czołowo-ciemieniowe, takimi jak: pamięć operacyjna (working memory), selektywność w zapamiętywaniu informacji oraz elastyczne korzystanie z zasobów pamięciowych [24].

Pamięć operacyjna to - w uproszczeniu - zdolność do krótkotrwałego utrzymywania i świadomego przetwarzania informacji potrzebnych, by wykonać określone zadanie. Korzystny wpływ polaryzacji mózgu na wskaźniki pamięci operacyjnej u chorych po udarze wykazali Jo i wsp. [25]. W badaniu naprzemiennym prowadzonym w warunkach ślepej próby i z grupą kontrolną, w której pozorowano stymulację, wzięło udział 10 chorych po udarze prawej półkuli mózgu, uczestniczących we wczesnej (1-4 miesiące od udaru) terapii zaburzeń poznawczych. Pacjentów poddano w losowej kolejności pojedynczym zabiegom stymulacji anodowej ( $2 \mathrm{~mA}$ przez $30 \mathrm{~min}$ ) i pozorowanej ( $2 \mathrm{~mA}$ przez $10 \mathrm{~s}$ ) rejonu grzbietowo-bocznej kory przedczołowej lewej półkuli mózgu (F3 wg EEG 10/20), $z$ umieszczeniem elektrody odniesienia nad prawą okolicą nadoczodołową. Bezpośrednio przed zabiegiem oraz po zabiegu stymulacji badani wykonywali test werbalnej pamięci operacyjnej przygotowany wg popularnego schematu eksperymentalnego, zwanego "n-wstecz” (n-back), polegający na zapamiętywaniu kolejno prezentowanych liter i ocenie ich zgodności z literą prezentowaną dwa bodźce wcześniej (wariant "2-wstecz”). Wyniki badania potwierdziły zakładany związek a-tDCS lewej kory przedczołowej ze wzrostem zapamiętywania i przetwarzania danych werbalnych, w związku z lewopółkulową dominacją dla funkcji językowych [25].

W ostatnich latach opublikowano wyniki dwóch badań dokumentujących pozytywny wpływ polaryzacji mózgu na sprawność uwagi dowolnej. Funkcje uwagi są bezpośrednio powiązane z procesami aktywacji mózgu: elementarne stany uwagi determinowane są poziomem wzbudzenia regulowanym przez układ siatkowaty pnia, wzgórze i przyśrodkowe struktury przedczołowe; ukierunkowanie uwagi w przestrzeni dokonuje się głównie dzięki aktywności okolic ciemieniowych, a świadoma i selektywna kontrola uwagowa zachowania związana jest z okolicami przedczołowymi. W pierwszym z badań, Harza i wsp. [26] ocenili wpływ tDCS na funkcjonowanie chorego po udarze prawopółkulowym, które to uszkodzenie doprowadziło do lewostronnego zaniedbywania wzrokowo-przestrzennego. Zespół ten przejawia się słabym reagowaniem na bodźce wzrokowe 
pochodzące z lewej części przestrzeni i nadmierną skłonnością do patrzenia w prawo. Wskutek tego poddany badaniu chory w prostym zadaniu dzielenia poziomych linii na pół błędnie wskazywał punkty środkowe linii jako zlokalizowane po prawej stronie od rzeczywistych środków. Aby sprawdzić, czy uda się poprawić symetrię rozkładu uwagi, u chorego przeprowadzono elektrostymulację anodową, katodową (po $10 \mathrm{~min}$ ) i pozorowaną okolic styku skroniowo-ciemieniowo-potylicznego obu półkul mózgu. Po anodowym wzbudzaniu rejonu styku półkuli prawej (uszkodzonej) z jednoczesnym katodowym hamowaniem homologicznej okolicy półkuli lewej chory celniej wskazywał środki linii w testowaniu bezpośrednim i odroczonym o $10 \mathrm{~min}$, choć w późniejszych pomiarach już nie notowano poprawy. W przeciwieństwie do tych obserwacji, katodowa i pozorowana stymulacja półkuli uszkodzonej nie miała znaczenia dla uwagi przestrzennej.

$\mathrm{W}$ drugim badaniu funkcji uwagi, przeprowadzonym przez Kanga i wsp. [27], wzięło udział 10 chorych po udarze mózgu i grupa kontrolna osób zdrowych. Badanie miało układ naprzemienny, z podwójnie ślepa próbą i pozorowaniem stymulacji. Chorzy byli znacznie zróżnicowani pod względem cech uszkodzenia mózgu (ogniska korowe i/lub podkorowe półkuli lewej bądź prawej) oraz czasu, jaki upłynął od zachorowania (od 23 dni do ponad 10 lat od udaru). Losowo poddano ich zabiegom stymulacji anodowej ( $2 \mathrm{~mA}$ przez $20 \mathrm{~min}$ ) i pozorowanej ( $2 \mathrm{~mA}$ przez $1 \mathrm{~min}$ ) nacelowanej na grzbietowo-boczną korę przedczołową lewej półkuli mózgu, z przyłożeniem elektrody odniesienia nad prawą okolicą nadoczodołową. Funkcje uwagi badano za pomocą testu „działaj-stop” (Go/No-Go), który mierzy podtrzymywanie uwagi i zdolność hamowania impulsywnych zachowań. Jego formuła sprowadza się do wywołania określonej reakcji w odpowiedzi na wyznaczony bodziec i powstrzymywania się od aktywności przy pojawieniu się bodźca alternatywnego (w eksperymencie było to naciśnięcie przycisku po wyświetleniu cyfry „1” i niereagowanie na cyfrę „2”). Porównanie wyników zebranych w różnych warunkach stymulacyjnych pokazało brak istotnych zależności między wskaźnikami uwagi a typem stymulacji u osób zdrowych, a w grupie chorych - wzrost dokładności reagowania po faktycznej stymulacji. Korzystny wpływ a-tDCS na jakość wykonania zadania uwagowego odnotowano nie tylko bezpośrednio po elektrostymulacji, lecz także w pomiarach kontrolnych przeprowadzonych 1 i 3 godziny po zabiegu.

Skrócony opis przedstawionych badań zawarto w tab. 1 .

\section{Stosowanie przezczaszkowej stymulacji prądem stałym u osób $z$ chorobami zwyrodnieniowymi mózgu}

Użyteczności metody tDCS poszukuje się też w terapii chorych ze zwyrodnieniowymi schorzeniami mózgu przebiegającymi z zaburzeniami poznawczymi i emocjonalno-osobowościowymi. Ocena efektywności leczniczej zabiegów elektrycznych w tej grupie chorych jest komplikowana dużym indywidualnym zróżnicowaniem objawów i ich postępującym charakterem oraz częstym jednoczesnym stosowaniem farmakoterapii, wpływającej na zjawiska neurofizjologiczne zależne od działania prądu [12].

Najwcześniej zainteresowano się efektywnością tDCS w usprawnianiu funkcji poznawczych u osób z chorobą Parkinsona. W schorzeniu tym do zaburzeń ruchowych dołącza się często deficyt poznawczy spowodowany dysfunkcją sieci korowo-wzgórzowo-podstawnych i zakłóceniem wewnątrzpółkulowych interakcji hamujących w obrębie płatów czołowych. Dlatego w obrazie klinicznym występują zaburzenia planowania i organizowania złożonej aktywności, czyli tzw. dysfunkcje wykonawcze, w tym upośledzenie pamięci operacyjnej. Zmiana czynności sieci korowo-podkorowych poprzez modulację kory mózgowej mogłaby zatem okazać się korzystna. Problem ten podjęli Boggio i wsp. [28], którzy poddali polaryzacji mózgu 18 osób z chorobą Parkinsona. U badanych 12 godz. przed elektrostymulacją odstawiano leki przeciwparkinsonowskie w związku z coraz liczniejszymi doniesieniami o pozytywnym wpływie dopaminy na aktywację kory przedczołowej i przebieg procesów pamięciowych. Całą grupę poddano 20-minutowej stymulacji anodowej grzbietowo-bocznej kory przedczołowej lewej półkuli mózgu, z przyłożeniem elektrody odniesienia nad prawą kością czołową, z tym, że u połowy pacjentów zastosowano prąd o natężeniu $1 \mathrm{~mA}$, a u pozostałych $2 \mathrm{~mA}$. Aby ocenić swoistość efektów anodowych, porównano je z rezultatami a-tDCS lewego pola ruchowego dla ręki i 30-sekundową pozorowaną a-tDCS. Wskaźnikiem werbalnej pamięci operacyjnej był wynik zadania „3-wstecz” (zapamiętywanie kolejnych liter $\mathrm{i}$ ich sukcesywne porównywanie $\mathrm{z}$ literami prezentowanymi trzy bodźce wcześniej) wykonywanego w ciągu ostatnich 5 min każdego z zabiegów. Wyniki eksperymentu potwierdziły wpływ wzmacniania aktywności kory przedczołowej na poprawę pamięci operacyjnej, ale tylko w przypadku prądu o natężeniu $2 \mathrm{~mA}$. Prąd o mniejszym natężeniu $(1 \mathrm{~mA})$, a także pozorowane i lokalizacyjnie nieswoiste dla pamięci werbalnej stymu- 


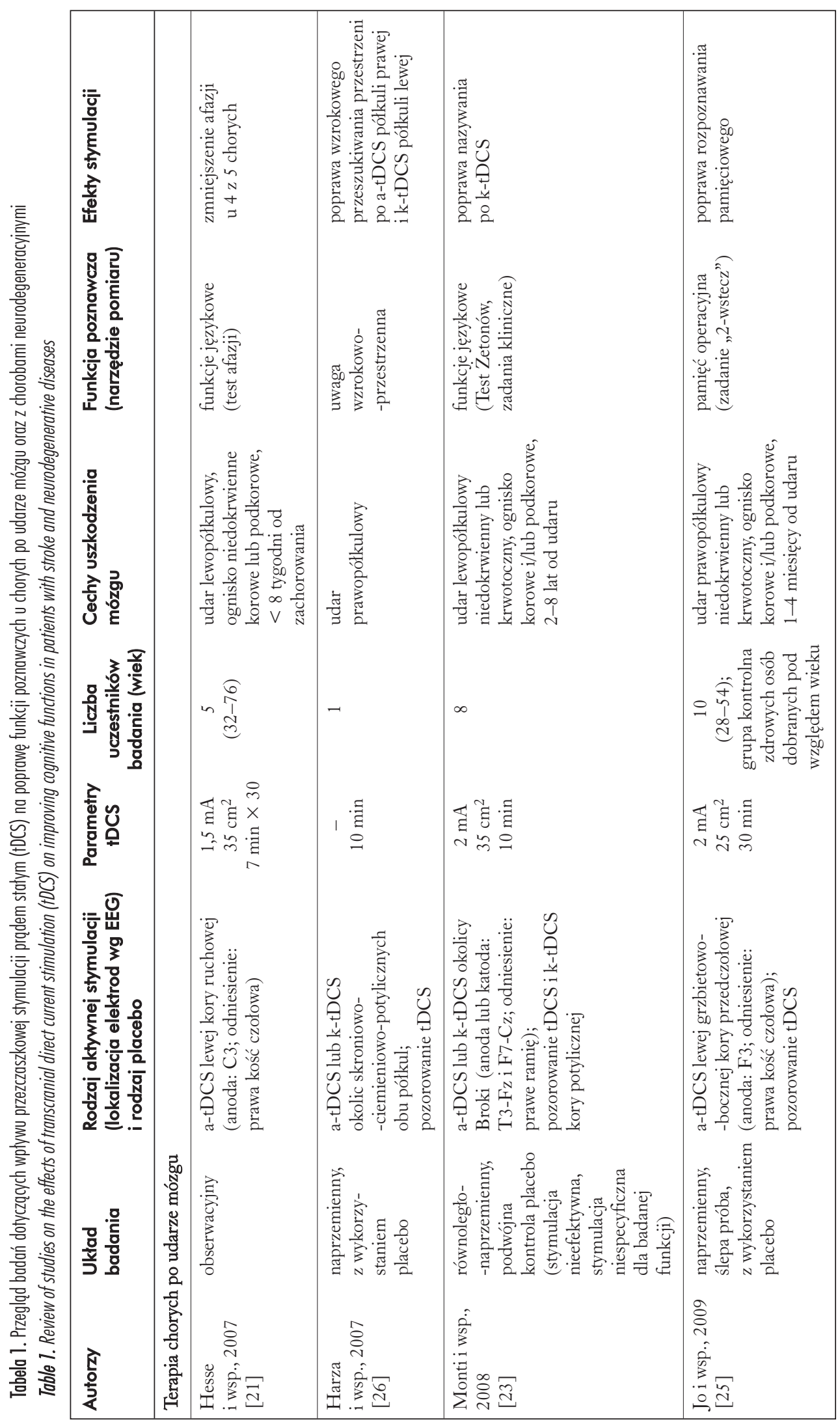




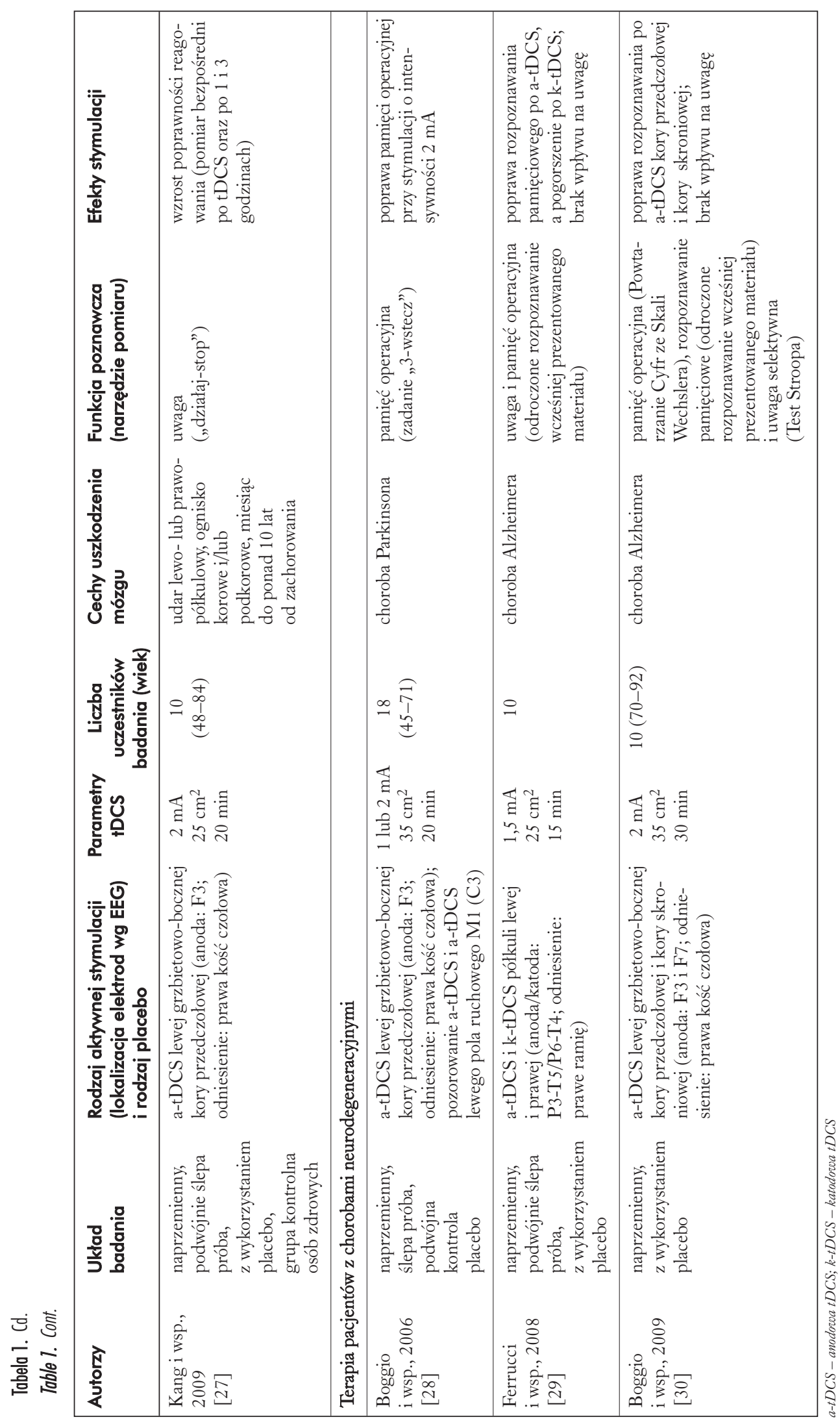


lowanie struktur czołowych (kora ruchowa) nie spowodowały istotnej zmiany funkcji pamięciowych. Obserwacje te przyczyniły się do włączenia siły elektrostymulacji do grupy ważnych zmiennych neuromodulacyjnych.

Badania prowadzono także wśród osób z prawdopodobną chorobą Alzheimera. U osób starszych otępienie typu alzheimerowskiego jest najczęstszą przyczyną upośledzenia zdolności uczenia się i przypominania wcześniej przyswojonych informacji, a stopniowo też niezdolności do rozpoznawania pamięciowego oraz narastania deficytów uwagi i innych dysfunkcji poznawczych. Przyczyną zaburzeń jest postępujący od okolic skroniowo-ciemieniowych zanik mózgu, wyrażający się m.in. obniżeniem poziomu ich wzbudzenia. By sprawdzić, czy neuromodulacja hipoaktywnych okolic doprowadzi do zmiany wskaźników pamięciowych i uwagowych, Ferrucci i wsp. [29] poddali grupe 10 pacjentów stymulacji anodowej, katodowej $(1,5 \mathrm{~mA}$; $15 \mathrm{~min})$ i pozorowanej $(1,5 \mathrm{~mA} ; 10 \mathrm{~s})$ zarówno lewej (P3-T5 wg EEG 10/20), jak i prawej (P6-T4) półkuli mózgu. Przepływ prądu zapewniała elektroda odniesienia przymocowana nad prawym mięśniem naramiennym. W sumie wykonano 6 zabiegów w co najmniej tygodniowych odstępach. Bezpośrednio przed każdym zabiegiem i pół godziny po nim chorzy wykonywali zadanie rozpoznawania słów (głośne czytanie pojedynczo prezentowanych słów $\mathrm{i}$ ich odroczone rozpoznawanie $\mathrm{w}$ zestawie $\mathrm{z}$ innymi słowami) oraz test uwagi wzrokowej (reagowanie na bodźce prezentowane stronnie w polu widzenia, poprzedzane sygnałem zgodnym lub niezgodnym z miejscem prezentacji bodźca docelowego). Podobnie jak w badaniach chorych po udarze mózgu, efekty stymulacji okazały się zależeć od biegunowości elektrod, tzn. a-tDCS spowodowała poprawę zdolności rozpoznawania, a k-tDCS jej pogorszenie, w porównaniu z placebo. Niestety, autorzy nie przeanalizowali oddzielnie efektów neuromodulacji lewej i prawej półkuli mózgu, co byłoby ciekawe w związku z lewopółkulową specjalizacją dla przetwarzania materiału słownego. Uwaga wzrokowa, oceniana na podstawie czasu reakcji na bodźce stronne, nie zmieniła się pod wpływem prądu stałego.

Wyniki powyższego eksperymentu zainspirowały Boggia i wsp. [30] do dokładniejszego zbadania zależności między a-tDCS a pamięcią i uwagą dowolną. Badacze poddali 10 pacjentów z chorobą Alzheimera niezależnym sesjom stymulacji anodowej lewej półkuli mózgu (2 mA; $30 \mathrm{~min})$ z przyłożeniem elektrody aktywnej nad grzbietowo-boczną korą przedczołową i korą skroniową, a także zabiegowi pozorowanemu ( $2 \mathrm{~mA}$; 30 s); elektrodę odniesienia mocowano nad prawą okolicą nadoczodołową. Wybór kory przedczołowej był podyktowany jej znaczeniem dla pamięci operacyjnej i uwagi selektywnej, a kory skroniowej (m.in. przyśrodkowe okolice skroniowe, hipokamp) - związkiem z długoterminową pamięcią deklaratywną. Do pomiaru uwagi selektywnej wykorzystano Test Stroopa (Stroop Test). Pamięć operacyjną oceniono za pomocą podtestu Powtarzania Cyfr ze Skali Inteligencji Wechslera, a do pomiaru rozpoznawania pamięciowego użyto zadania wzrokowego, polegającego na 10-sekundowej prezentacji obrazków i ich rozpoznawaniu w szerszym zestawie bodźców. Analiza danych ponownie potwierdziła pozytywny wpływ a-tDCS (zarówno kory przedczołowej, jak i skroniowej) na poprawę zdolności rozpoznawania i brak jej wpływu na uwagę. W przeciwieństwie jednak do wcześniejszych doniesień $[25,28]$ nie odnotowano związku polaryzacji anodowej z pamięcią operacyjną, mierzoną jednakże innym testem niż wcześniej (powtarzanie cyfr w porównaniu z zadaniami „n-wstecz”).

Opisane badania przedstawiono w tab. 1.

\section{Mechanizmy i uwarunkowania postymulacyjnych zmian poznawczych}

W większości przedstawionych schematów eksperymentalnych wykazano wpływ elektrostymulacji anodowej wybranych okolic uszkodzonego mózgu na poprawę funkcji językowych, pamięciowych i niektórych aspektów uwagi. Lepsze wykonanie zadań poznawczych po a-tDCS przypisywane jest zwykle wzrostowi poziomu wzbudzenia mózgowego i neuronalnej aktywności, zapewniającym korzystniejsze warunki neurofizjologiczne dla przebiegu procesów samonaprawczych i reorganizacji funkcjonalnej. Najliczniejsze dotąd badania nad wpływem a-tDCS na korę ruchową dowodzą, że po uszkodzeniach stronnych mózgu (np. wskutek udaru mózgu) wczesna reaktywacja lub nawet nadmierna aktywacja rejonów okalających ognisko martwicy silniej koreluje z dobrym zdrowieniem niż nadmierna aktywność homologicznych rejonów półkuli nieuszkodzonej [16], niewyspecjalizowanej lub niedominującej w regulacji określonej funkcji.

Poglądy naukowców na temat wpływu zmian wzbudzenia i aktywacji mózgu na aktywność poznawczą oscylują wokół dwóch koncepcji interpretacyjnych. $Z$ jednej strony uważa się, że przejawy neuroplastyczności modulowane przez tDCS mają charakter swoisty. Oznacza to, 
że polaryzacja wybranych części mózgu, ważnych dla regulacji określonych funkcji, powinna doprowadzić do względnie selektywnej poprawy tych funkcji. W tym kontekście najczęściej podkreśla się możliwość usprawnienia pamięci i zdolności uczenia się, które zapewniają sprawniejsze korzystanie z zasobów własnej wiedzy, nabywanie nowych wiadomości i umiejętności oraz adaptację do życia w zmieniających się warunkach. $Z$ drugiej jednak strony pojawiają się głosy, że poprawa poznawcza po elektrostymulacji przynajmniej częściowo może wynikać z nieswoistego wzrostu gotowości do reagowania na bodźce, zwanego stanem alertu [30] i/lub wsparcia precyzji i dynamiki przetwarzania wielomodalnego [24] - procesów ściśle zależnych od tonicznych i fazowych zwyżek wzbudzenia mózgowego, rzutujących w pierwszej kolejności na funkcje uwagi.

Za opcją interpretacyjną wskazującą na swoisty charakter postymulacyjnych efektów poznawczych najsilniej przemawia brak korelacji między polepszeniem wskaźników poznawczych po a-tDCS a szybkością reagowania na bodźce $[23,25,27,29,30]$. Dowodów dostarcza też wybiórcza poprawa funkcji pamięciowych i powiązanych z nimi zdolności u zdrowych wolontariuszy, u których po a-tDCS kory przedczołowej półkuli dominującej dla języka obserwowano lepsze wykonanie zadań w zakresie: fluencji słownej [32], aktualizacji nazw [33], werbalnej pamięci operacyjnej [34], uczenia się nowych pojęć [35] i rozwiązywania złożonych problemów werbalnych [36].

Badania neurofizjologiczne nad działaniem prądu na mózg $[9,37]$ oraz wiedza o neuronalnych podstawach pamięci i uczenia się $[38,39]$ pozwalają przypuszczać, iz swoiste efekty, notowane w pomiarach behawioralnych, wynikają z podprogowej modulacji potencjału spoczynkowego błon neuronalnych związanej z depolaryzującym (zwiększającym pobudliwość neuronalną) wpływem anody i hiperpolaryzacyjnym (hamującym przewodnictwo) działaniem katody. Wyzwolone zmiany pobudliwości są wzmagane i podtrzymywane w postaci efektu następczego dzięki mechanizmom synaptycznym, wśród których najważniejsze jest uruchomienie receptora NMDA (dla N-metylo-D-asparaginianu) i następowy proces długotrwałego wzmacniania synaptycznego (long-term potentiation - LTP) [1]. Pobudzenie kompleksu NMDA oraz LTP są niezbędne dla procesu uczenia się i innych przejawów neuroplastyczności [10]. Korzyści poznawcze mogą wynikać $\mathrm{z}$ nasilenia wymienionych zjawisk w wyróżnionych częściach układów neuronalnych dla określonych funkcji (np. w okolicy Wernickego lub Broki w systemie języ- kowym) bądź ze zmian zachodzących w strukturach powiązanych z tym układem (np. w lewym hipokampie wspierającym system językowy podczas uczenia się i przetwarzania materiału językowego) [35].

Hipotezy o znaczeniu zwiększonego wzbudzenia korowego dla sprawniejszego przebiegu procesów poznawczych nie potwierdza wynik badania Monti i wsp. [23]. Ujawniono w nim bowiem poprawę zdolności nazywania po hamującej stymulacji katodowej półkuli uszkodzonej. Podobnie jak inni badacze, Monti i wsp. spojrzeli na rezultat swych badań w kontekście interakcji międzypółkulowych, ale wskazali na hipotetyczny mechanizm wybiórczego blokowania przez katodę wewnątrzpółkulowych obwodów hamujących. Poprzez tłumienie aktywności hamującej może dojść do „odhamowania” struktur językowych, wzrostu ich aktywności i ujawnienia potencjału funkcjonalnego. Możliwość wystąpienia takiego mechanizmu sugerowali już inni badacze, m.in. Lang i wsp. [40] oraz Antal i wsp. [41].

Wydaje się, że druga koncepcja interpretacyjna, mówiąca o usprawnieniu poznawczym w mechanizmie nieswoistej poprawy odbioru i przetwarzania informacji pod wpływem tDCS, jest najbardziej przekonująca w przypadku funkcji uwagowych. Badania nad uwagą przestrzenną pokazują, że podobnie jak deficyt wzbudzeniowy mózgu (np. wywołany deprywacją snu lub działaniem leków) może łatwo doprowadzić do asymetrii rozkładu uwagi wzrokowej [42], tak zrównoważenie i wzmocnienie aktywacyjne półkul bezpośrednio niweluje ten defekt. Kolejnego dowodu klinicznego dostarczają rzadkie przypadki nagłej remisji poudarowego zespołu zaniedbywania po spadku nadmiernej aktywności półkuli wcześniej nieuszkodzonej w wyniku kolejnego udaru, tym razem w jej obszarze [43]. Analogiczny efekt poprawy uwagowej obserwowano po hamowaniu nadaktywnej półkuli metodą magnetostymulacji [44].

Zróżnicowanie wyników badań i ich interpretacji dowodzi, że zależności między biegunowością elektrod aktywnych a wskaźnikami behawioralnymi nie są proste i do końca poznane. Ważnymi zmiennymi neuromodulacyjnymi są: parametry i typ elektrostymulacji (natężenie prądu, pozycja i wielkość elektrod, stymulacja jedno- lub obupółkulowa), złożoność zadania poznawczego, a także rodzaj aktywności towarzyszącej stymulacji [1]. Eksperyment Boggia i wsp. [28] należy do grupy badań podkreślających rolę większego natężenia prądu dla uzyskania efektu behawioralnego. Metaanaliza anodowych stymulacji przedczołowych pokazuje, że podczas gdy prąd o natężeniu $1 \mathrm{~mA}$ nieznacznie poprawia wykonanie testu poznawczego, to 
natężeniu $2 \mathrm{~mA}$ towarzyszy zwykle wyraźna poprawa [36]. Poza tym badacze stosują elektrody o różnej powierzchni $\left(25 \mathrm{~cm}^{2}\right.$ lub $\left.35 \mathrm{~cm}^{2}\right)$, co rzutuje na gęstość podawanego prądu [stosunek natężenia prądu $(\mathrm{mA})$ do powierzchni elektrody $\left.\left(\mathrm{cm}^{2}\right)\right]$. Zastanawiające jest także funkcjonalne znaczenie katody, będącej elektrodą odniesienia w zabiegach anodowych. Nie można pominąć faktu, że przyłożenie katody nad biegunem czołowym jednej z półkul mózgu może hamować i zakłócać aktywność tego rejonu [1]. Na interferencyjny wpływ neuromodulacji katodowej na funkcje okolic przedczołowych wskazują m.in. badania Fecteau i wsp. [45]. Aby ograniczyć niekorzystny wpływ katody, można ją montować poza obrębem głowy lub zwiększyć jej rozmiar $[1,46]$, gdyż wraz ze wzrostem powierzchni elektrody spada gęstość przepływającego przez nią prądu i możliwość jego przenikania do mózgu.

Znaczenie dla efektywności tDCS może mieć również rodzaj ocenianej aktywności poznawczej. O ile początkowo analizowano jak najprostsze funkcje poznawcze w różnych warunkach stymulacyjnych, to obecnie ocenia się złożone zdolności angażujące wiele procesów poznawczych, regulowanych przez skomplikowane systemy neuronalne. Konsekwencją tego będą zapewne badania nad efektywnością stymulacji wielomiejscowej. Zagadnieniem do zbadania w przyszłości jest także analiza naukowa elektrostymulacji o wydłużonym czasie trwania, wielokrotnie powtarzanej i silniejszej niz dotychczasowa [1]. Wzmocnienie efektów terapeutycznych próbuje się osiągnąć, kojarząc tDCS z zabiegami magnetostymulacji i elektrostymulacji obwodowej czy z farmakoterapią. Badanie Marshalla i wsp. [47] wskazuje dodatkowo na pozytywny wpływ polaryzacji prowadzonej podczas głębokiego snu. Szczególnie duże nadzieje wiąże się jednak z łączeniem biernych zabiegów stymulacyjnych ze specyficznym treningiem zaburzonych czynności i zróżnicowaną terapią poznawczo-behawioralną, by potęgować korzyści funkcjonalne wynikające z wprowadzenia różnych metod. Zdaniem Robertsona i Murre'a [48], aby proces neurorehabilitacji przebiegał efektywnie, niezbędne jest podwyższenie poziomu neurofizjologicznego wzbudzenia. Funkcjonalna reorganizacja mózgu jest jednak bardziej dynamiczna przy aktywnym zaangażowaniu się w trening, stąd możliwe, że poprawa przekładająca się na codzienne funkcjonowanie będzie zintensyfikowana przy kombinacji interwencji wzmagających poziom wzbudzenia z terapią behawioralną. Łagodne zabiegi elektryczne mogą typowo poprzedzać, towarzyszyć bądź następować po tej terapii, ponieważ nie są szczególnie uciążliwe.

\section{Podsumowanie}

Przezczaszkowa stymulacja prądem stałym jest ciagle weryfikowaną eksperymentalnie metodą wspomagania terapii dysfunkcji poznawczej u chorych z uszkodzeniem mózgu. Wstępne badania wskazują na pozytywny wpływ nawet jednorazowych zabiegów anodowej tDCS. Wciąż mało wiadomo na temat czasu utrzymywania się postymulacyjnych efektów, a potęgowanie korzyści terapeutycznych poprzez powtarzanie zabiegów i łączenie ich z innymi formami rehabilitacji jest zagadnieniem otwartym. Nie wiadomo, czy poprawa uzyskana w zakresie jakiejkolwiek zdolności wtórnie wpływa na usprawnienie innych funkcji i czy przekłada się to na codzienną aktywność chorego. Jeśli dalsze badania potwierdzą oczekiwania wiązane z tDCS, metoda ta ma duże szanse na upowszechnienie, gdyż jest prosta, bezpieczna, bezbolesna i niedroga.

\section{Oświadczenie}

Autorzy zgłaszają brak konfliktu interesów.

\section{Piśmiennictwo}

1. Nitsche M.A., Cohen L.G., Wassermann E.M. i wsp. Transcranial direct current stimulation: State of the art 2008. Brain Stimul 2008; 1: 206-223.

2. Priori A., Berardelli A., Rona S. i wsp. Polarization of the human motor cortex through the scalp. Neuroreport 1998; 9: 2257-2260.

3. Palińska D., Sobów T., Kłoszewska I. Zabiegi elektrowstrząsowe dwuczołowe - skuteczność i tolerancja w porównaniu z elektrowstrząsami jednostronnymi i dwuskroniowymi. Post Psychiatr Neurol 2005; 14: 205-207.

4. Kalinowski A. Elektrowstrząsy - wciąż użyteczna metoda leczenia depresji. Terapia 2003; 11: 16-18.

5. Nitsche M.A., Liebetanz D., Lang N. i wsp. Safety criteria for transcranial direct current stimulation (tDCS) in humans. Clin Neurophysiol 2003; 114: 2220-2222.

6. Lang N., Siebner H.R., Ward N.S. i wsp. How does transcranial DC stimulation of the primary motor cortex alter regional neuronal activity in the human brain? Eur J Neurosci 2005; 22: 495-504.

7. Priori A., Berardelli A., Rona S. i wsp. Polarization of the human motor cortex through the scalp. Neuroreport 1998; 9: 2257-2260.

8. Nitsche M.A., Paulus W. Excitability changes induced in the human motor cortex by weak transcranial direct current stimulation. J Physiol 2000; 527: 633-639.

9. Nitsche M.A., Seeber A., Frommann K. i wsp. Modulating parameters of excitability during and after transcranial direct current stimulation of human motor cortex. J Physiol 2005; 568 : 291-303.

10. Nitsche M.A., Fregni F. Transcranial direct current stimulation - an adjuvant tool for the treatment of neuropsychiatric diseases? Curr Psychiatr Rev 2007; 3: 222-232.

11. Polanowska K., Seniów J., Członkowska A. Zasady stosowania i mechanizm działania przezczaszkowej stymulacji prądem stałym 
w neurorehabilitacji: dane z badań kory ruchowej. Neurol Neurochir Pol 2010; 44: 172-180.

12. Fregni F., Pascual-Leone A. Technology insight: noninvasive brain stimulation in neurology - perspectives on the therapeutic potential of rTMS and tDCS. Nat Clin Pract Neurol 2007; 3: 383-393.

13. Rijntjes M. Mechanism of recovery in stroke patients with hemiparesis or aphasia: new insight, old questions and the meaning of therapies. Curr Opin Neurol 2006; 19: 76-83.

14. Gandiga P.C., Hummel F.C., Cohen L.G. Transcranial DC stimulation (tDCS): a tool for double-blind sham-controlled clinical studies in brain stimulation. Clin Neurophysiol 2006; 117 : 845-850.

15. Schlaug G., Renga V. Transcranial direct current stimulation: a noninvasive tool to facilitate stroke recovery. Expert Rev Med Devices 2008; 5: 759-768.

16. Schlaug G., Renga V., Nair D. Transcranial direct current stimulation in stroke recovery. Arch Neurol 2008; 65: 1571-1576.

17. Webster B.R., Celnik P.A., Cohen L.G. Noninvasive brain stimulation in stroke rehabilitation. NeuroRx 2006; 3: 474-481.

18. Reis J., Swayne O.B., Vandermeeren Y. i wsp. Contribution of transcranial magnetic stimulation to the understanding of cortical mechanisms involved in motor control.J Physiol 2008; 586: 325-351.

19. Perani D., Cappa S.F., Tettamanti M. i wsp. An fMRI study of word retrieval in aphasia. Brain Lang 2003; 85: 357-368.

20. Saur D., Lange R., Baumgaertner A. i wsp. Dynamics of language reorganization after stroke. Brain 2006; 129: 1371-1384.

21. Hesse S., Werner C., Schonhardt E.M. i wsp. Combined transcranial direct stimulation and robot-assisted arm training in subacute stroke patients: a pilot study. Restor Neurol Neurosci 2007; 25: 9-15.

22. Kreisel S.H., Hennerici M.G., Bäzner H. Pathophysiology of stroke rehabilitation: The natural course of clinical recovery, use-dependent plasticity and rehabilitative outcome. Cerebrovasc Dis 2007; 23: 243-255.

23. Monti A., Cogiamanian F., Marceglia S. i wsp. Improved naming after transcranial direct current stimulation in aphasia. J Neurol Neurosurg Psychiatry 2008; 79: 451-453.

24. Sparing R., Mottaghy F.M. Noninvasive brain stimulation with transcranial magnetic or direct current stimulation (TMS/tDCS) - from insights into human memory to therapy of its dysfunction. Methods 2008; 44: 329-337.

25. Jo J.M., Kim Y.-H., Ko M.-H. i wsp. Enhancing the working memory of stroke patients using tDCS. Am J Phys Med Rehabil 2009; 88: 404-409.

26. Harza I., Antal A., Paulus W. i wsp. Transcranial direct current stimulation improves perceptual performance in a patient with unilateral neglect. Clin Neurophysiol 2007; 118: e42-e42.

27. Kang E.K., Min J.B., Kim S.Y. i wsp. Non-invasive cortical stimulation improves post-stroke attention decline. Restor Neurol Neurosci 2009; 27: 645-650.

28. Boggio P.S., Ferucci R., Rigonatti S.P. i wsp. Effects of transcranial direct current stimulation on working memory in patients with Parkinson's disease. J Neurol Sci 2006; 249: 31-38.

29. Ferrucci R., Mameli F., Guidi I. i wsp. Transcranial direct current stimulation improves recognition memory in Alzheimer disease. Neurology 2008; 71: 493-498.

30. Boggio P.S., Khoury L.P., Martins D.C.S. i wsp. Temporal cortex direct current stimulation enhances performance on a visual recognition memory task in Alzheimer disease. $J$ Neurol Neurosurg Psychiatry 2009; 80: 444-447.

31. Paus T. Functional anatomy of arousal and attention systems in the human brain. W: Uylings H.B.M., Van Eden J.P.C., De Bruin M.G.P. i wsp. [red.]. Progress in brain research. Elsevier Science B. V., 2000, ss. 65-77.

32. Iyer M.B., Mattu U., Grafman J. i wsp. Safety and cognitive effects of frontal DC brain polarization in healthy individuals. Neurology 2005; 64: 872-875.

33. Fertonani A., Rosini S., Cotelli M. i wsp. Naming facilitation induced by transcranial direct current stimulation. Behav Brain Res 2010; 208: 311-318.

34. Fregni F., Boggio P.S., Nitsche M. i wsp. Anodal transcranial direct current stimulation of prefrontal cortex enhances working memory. Exp Brain Res 2005; 166: 23-30.

35. Flöel A., Rösser N., Michka O. i wsp. Noninvasive brain stimulation improves language learning. J Cogn Neurosci 2008; 20: 1415-1422.

36. Cerruti C., Schlaug G. Anodal transcranial direct current stimulation of the prefrontal cortex enhances complex verbal associative thought. J Cogn Neurosci 2009; 21: 1980-1987.

37. Liebetanz D., Nitsche M.A., Tergau F. i wsp. Pharmacological approach to the mechanisms of transcranial DC-stimulationinduced after-effects of human motor cortex excitability. Brain 2002; 125: 2238-2247.

38. Rioult-Pedotti M.S., Friedman D., Hess G. i wsp. Strengthening of horizontal cortical connections following skill learning. Nat Neurosci 1998; 1: 230-234.

39. Rioult-Pedotti M.S., Friedman D., Hess G. i wsp. Learninginduced LTP in neocortex. Science 2000; 290: 533-536.

40. Lang N., Nitsche M.A., Paulus W. i wsp. Effects of transcranial direct current stimulation over the human motor cortex on corticospinal and transcallosal excitability. Exp Brain Res 2004; 156: 439-443.

41. Antal A., Nitsche M.A., Paulus W. Transcranial direct current stimulation and the visual cortex. Brain Res Bull 2006; 68: 459-463.

42. Fimm B., Willmes K., Spijkers W. The effect of low arousal on visuo-spatial attention. Neuropsychologia 2006; 44: 1261-1268.

43. Vuilleumier P., Hester D., Assal G. i wsp. Unilateral spatial neglect recovery after sequential strokes. Neurology 1996; 46: 184-189.

44. Oliveri M., Bisiach E., Brighina F. i wsp. RTMS of the unaffected hemisphere transiently reduces contralesional visuospatial hemineglect. Neurology 2001; 57: 1338-1340.

45. Fecteau S., Pascual-Leone A., Zald D.H. i wsp. Activation of prefrontal cortex by transcranial direct current stimulation reduces appetite for risk during ambiguous decision making. J Neurosci 2007; 27: 6212-6218.

46. Boggio P.S., Fregni F., Valasek C. i wsp. Temporal lobe cortical electrical stimulation during the encoding and retrieval phase reduces false memories. PLoS ONE 2009; 4: e4959.

47. Marshall L., Mölle M., Hallschmid M. i wsp. Transcranial direct current stimulation during sleep improves declarative memory. J Neurosci 2004; 24: 9985-9992.

48. Robertson I.H., Murre J.M. Rehabilitation of brain damage: brain plasticity and principles of guided recovery. Psychol Bull 1999; 125 : 544-575. 